DOI: https://doi.org/10.34069/AI/2021.48.12.28

How to Cite:

Shvydun, L., Krapivnyk, G., Dvornichenko, L., \& Korzh, H. (2021). Axiological constants of educational mobility. Amazonia Investiga, 10(48), 264-273. https://doi.org/10.34069/AI/2021.48.12.28

\title{
Axiological constants of educational mobility
}

\section{Аксіологічні константи освітньої мобільності}

Received: October 30, 2021

Received: October 30,2021

Accepted: December 17, 2021

\begin{abstract}
The article analyzes the process of educational mobility in terms of educational philosophy. The philosophical and axiological constants of educational mobility allow us to clearly indicate the purpose of this process. Advantages and disadvantages of mobility form value priorities in integration educational cluster. Values are a litmus test of expediency and effectiveness of mobility for subjects of education and educational system. Axiological human dimension of education ensures its sustainable progressive development, while integration is only a tool to ensure it. The aim of the work is to develop a system of axiological norms formed in the process of educational mobility. It is practically impossible to create a universal system of values for the educational sphere, so we consider dialectical contradictions of sociocultural categories as an acceptable methodology for the formation of relevant mobility axiological constants. Contradictions of globalization and identification trends, imbalance of in formativeness and communicativeness of educational process, contradictions in issues of openness and accessibility of education, correlation of pragmatic and humanistic ideas in learning, classification of horizontal and vertical forms of mobility are the categories that provide
\end{abstract}

Анотація

У статті аналізується процес освітньої мобільності з точки зору філософії освіти. Філософсько-аксіологічні константи освітньої мобільності дозволяють чітко вказати на мету цього процесу. Переваги та недоліки мобільності формують ціннісні пріоритети в інтеграційному освітньому кластері. Цінності - це лакмусовий папірець доцільності та ефективності мобільності для суб'єктів освіти та системи освіти. Аксіологічний людський вимір освіти забезпечує її стійкий поступальний розвиток, a інтеграція $\epsilon$ лише інструментом його забезпечення. Метою роботи $\epsilon$ розробка системи аксіологічних норм, що формуються в процесі освітньої мобільності. Створити універсальну систему цінностей для освітньої сфери практично неможливо, тому ми розглядаємо діалектичні суперечності соціокультурних категорій як прийнятну методологію формування відповідних аксіологічних констант мобільності. Протиріччя глобалізації та ідентифікаційних тенденцій, дисбаланс інформативності та комунікативності навчального процесу, суперечності в питаннях відкритості та доступності освіти, співвідношення прагматичних i гуманістичних ідей $\mathrm{y}$ навчанні, класифікація горизонтальних i

\footnotetext{
${ }^{116}$ Senior Lecturer Department of Preschool and Primary Education Communal Institution of Higher Education «Dnipro Academy of Continuing Education» Dnipropetrovsk Regional Council», Ukraine.

${ }^{117}$ DSc in Philosophy, PhD in Philology, Associate professor Department of English Philology H.S. Skovoroda Kharkiv National Pedagogical University, Ukraine.

${ }^{118} \mathrm{PhD}$ of philosophical sciences, docent Associate professor the Department of Psychology A.S. Makarenko Sumy Pedagogical University Romenska, Ukraine.

${ }^{119} \mathrm{PhD}$ of philosophical sciences Associate professor at the Department of Philosophy at G.S. Skovoroda National Pedagogical University the Department of Philosophy H. S. Skovoroda Kharkiv National Pedagogical University, Ukraine.
} 


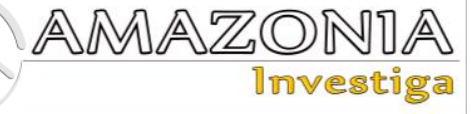

a common understanding of value priorities in education.

Keywords: axiology, human dimension of education, educational mobility, educational values, social philosophy, philosophy of education.

\section{Introduction}

When it comes to mobility related to human activity, there is immediately a confrontation between anthropological and axiological philosophical aspects. Educational mobility is also the object of this dichotomy. Philosophy of education has two key constants:

- human dimensionality, indicating that man as an individual and as a member of society is a seeker of education (in all manifestations - from school, higher or professional to selfeducation) and with this process is associated with the application of various components of human activity (intellectual, social, physiological) and the like);

- value dimension, indicating not the form of the educational process, but the purpose and content of the educational process, which must include material and spiritual values that appear as a result of education.

Based on this interpretation of educational philosophy, we can outline a philosophical understanding of educational mobility. The notion of mobility is associated more with physical quantities (movement, direction, dynamics).

Educational mobility extrapolates all these constants into the human dimension (since a person is a co-inventor and organizer of education) and the field of values (since the axiological constant is the key goal of education along with the gnoseological one).

The traditional opposition of dialectical categories of form and content, quantity, and quality most fully express the philosophical interpretation of educational mobility. On the one hand, the educational process forms the properties of its own mobility on the basis of human potential. On the other hand, it exacerbates the need for a balance of values in the course of this mobility. These two approaches (anthropological and axiological) in the problem of educational mobility are at different poles and partly openly oppose each other. Scholars who study the problems of the philosophy of education face difficult questions concerning the вертикальних форм мобільності - це ті категорії, які забезпечують спільне навчання. розуміння ціннісних пріоритетів в освіті.

Ключові слова: аксіологія, людський вимір освіти, освітня мобільність, освітні цінності, соціальна філософія, філософія освіти.

ordering of the value aspects of educational mobility.

After all, every phenomenon or process of social manifestation is immediately burdened by the need to establish a clear normative framework. Ironically, the field of education also needs such a methodological approach, since disorder creates a certain chaotic nature, which is unacceptable for the educational cluster. The authors of the study propose to introduce axiological constants of educational mobility:

- identification principle of educational mobility in the paradigm of globalization;

- communicative norms for subjects of educational mobility in contemporary progressive interpretations of educational philosophy;

- target component of the educational mobility process in its humanistic-pragmatic manifestation;

- $\quad$ social tolerance in the horizontal and vertical forms of educational mobility;

- individual value priorities in categorical manifestations: openness, accessibility, efficiency, responsibility as categories of educational philosophy.

The purpose of this study is to develop a system of axiological norms formed in the process of educational mobility. From the philosophicaltheoretical and scientific-practical points of view such values are designed to perform important functions that ensure the quality of the educational process as a whole. Mobility includes social, individual, natural, physiological aspects, which must be considered when organizing the educational process. Consequently, it is proposed to determine the value priorities of the process of educational mobility through dialectical categories: globalization-identity, informativenesscommunicativeness, horizontality-verticality (socio-philosophical aspect), pragmatismhumanism, responsibility. 


\section{Theoretical Framework or Literature Review}

The problem of educational mobility has been highlighted in scientific research in parallel with the spread of this process. Philosophical reflection on the positive and negative aspects of educational mobility became relevant after the first successes and problems of this phenomenon began to appear. A general characterization of social mobility was indicated in the philosophical and cultural perspectives of Sorokin (1992). Urry (2000) classified types of mobility, which allowed further definition of types of educational mobility. Important for understanding the peculiarities of the process of educational mobility is a study of educational mobility in individual regions or countries.

Educational mobility is a concept spelled out in declarative and legislative documents of countries and organizations Bologna Declaration (1999) and Sorbonne Joint Declaration (1998). We find philosophical and axiological aspects of educational mobility in the works of Torche (2019), Gruijters, Chan \& Ermisch (2019), Chow \& Guppi (2021), Manchul (2021), Yang \& Cheng (2018), Engzell \& Trop (2019). Approving sentiments about the process of educational mobility prevail in Ukrainian academic opinion. Shvydun (2021), Myhovych (2019), Prokhorenko (2017), Andrushchenko \& Svyrydenko (2016) highlight mobility in education (and from the perspective of educational philosophy), comparing the implementation of this process with other areas.

\section{Methodology}

In this study were used general and specialized methods of scientific knowledge. Through the analysis and synthesis conducted a general theoretical interpretation of the value components of the process of educational mobility. The method of comparison provided an explanation of anthropological and axiological approaches to understanding the social nature of educational mobility. Dialectical philosophical method allowed to investigate categorical oppositions of key axiological constants of educational mobility. Application of synergetic transdisciplinary methodology provides a study of the process of educational mobility in the aspect of self-organization, which is a fundamental principle of educational philosophy.

\section{Results and Discussion}

Before considering the philosophical aspects of educational mobility, we should clarify the essence of the concept of "mobility" in terms of its social nature. The problem of educational mobility is sociological, but if we take the philosophical aspect, we are talking about the philosophy of education cluster. Modern philosophy develops the ideas of social stratification and social mobility, proposed by Sorokin (1992) back in the middle of the XX century. The key model of such an interpretation is the denial of class and the introduction of stratification of society. The idea of execution is not the fixity of social belonging, but the efficacy of a member of a particular social stratum. Social mobility enables dynamic movements along social ladders or elevators. Philosophy of education not only organizes the learning process, but also gives it value reflections of social and individual character. Under such conditions, the educational sphere becomes a full-fledged player in socio-philosophical paradigms. And the concept of educational mobility becomes an effective tool to ensure not only the dynamics of the subjects of the educational process, but also to form its value orientations. One of the axiological constants proposed by the authors of the study is social tolerance in the horizontal and vertical form of educational mobility. The peculiarity of this value component is to ensure the interests of all participants in the process of educational mobility. In practice, the transition between executions is social mobility. There are horizontal and vertical forms of mobility (Urry, 2000).

Such a classification is also appropriate for educational mobility, since socio-psychological reflections are basic to the philosophy of education. Horizontal educational mobility is the movement of participants in the educational process within one educational system (state, professional, regional) or a change of place of study or teaching (or scientific activity). A similar classification is observed in the documents of the Bologna process, where academic mobility has two dimensions: vertical, which is reduced to the study of a student in another university, at the end of which he receives a degree; horizontal, providing training in another university for a certain period, after which the student returns to the alma mater and continues training. According to the principles of the Bologna process, a distinction is made between degree mobility (diploma/degreemobility) as learning that ends with a degree, and credit mobility (coredit/temporarymobility) as learning that accumulates credits (The Bologna Declaration, 1999). 


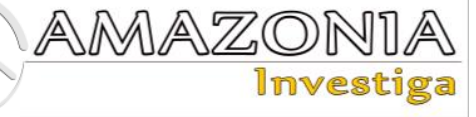

The Sorbonne Declaration (1998) declares attempts by educational governments to continue to encourage new ways of acquiring and validating acquired knowledge. Progressive harmonization can be achieved by building on existing experience and organizing dialogue with all stakeholders.

Oksamytna (2011) adds several more types of social mobility, which allow the development of philosophical and axiological components of the educational cluster. In particular, structural mobility is noted, which involves the movement of individuals due to changes in the production process or economic structure; exchange mobility (circulating) is characterized by the process of social alignment of opportunities and accessibility to different social positions.

Philosophy of education as a branch of philosophy projects the vectors of development of the social component. Educational mobility is also interpreted by Kalinicheva (2015) in terms of geographic, state, or administrative character. The following types of academic mobility are distinguished: a) direct mobility - the movement of subjects of the educational process outside the country (abroad); b) reverse mobility - the arrival of foreigners for training or research activities; c) export (external) mobility - from the perspective of the student's supplying country; d) imported mobility (input) mobility - the migration educational component from the perspective of the donor country. In this case it is important to understand the risks of mobility for countries, regions, or communities with a low level of economic development.

There is a situation where the outflow of personnel aggravates the crisis and makes it impossible to conduct reforms or to conduct current affairs due to the banal lack of qualified personnel. Social tolerance in such conditions implies the regulation of outflows and the equitable distribution of human educated potential. The philosophical interpretation of educational mobility originates not in the anthropological characteristics of the process, but in value contradictions. Inequality of educational achievement is one of the wellestablished and constantly reproduced inequalities in any society. The peculiarity is that the final result of the learning process is always inequality, but the very process of obtaining by individuals of different levels of education is formally determined on the basis of equal access and even partial compulsion for all.
The social institution of education actually plays an intermediary role in the process of legitimizing, "justifying" other forms of social inequality, which are based on unequal distribution of such social resources as income, wealth, power, prestige, and access to which for an adult usually opens on the basis of his education. Education has become a social resource, important not only as an indicator of a person's education and the acquisition of a certain specialty, but also as the main channel of social reproduction and social mobility. As for modern societies, the distinction between two types of inequality is considered fundamentally important. The first is the so-called inequality of positions, which (primarily employment positions) are characterized by unequal rewards, access to basic social resources such as income, prestige, and power. The other is commonly known as inequality of opportunity, that is, inequality of access to the most social class positions. The social justice of social inequality as unequal rewards for work performed or potential work, effort, and merit is generally unquestioned and unobjectionable.

However, inequality of opportunity is recognized as an injustice. It is the accessibility of education to the able and motivated that is considered a certain benchmark, defined as meritocracy. Meritocracy is a targeted component of educational mobility, as it prepares the wealthiest citizens to lead the country (Oksamytna, 2011). The concept of meritocracy fully expresses not just socio-philosophical results, but appears as the goal of educational philosophy in a general sense.

Globalization fully determines the vectors of development and the axiological orientation of the education system as a whole and of specific educational content. Today, the actualization of educational value components is associated with: humanization (the assertion of human measurement as the highest social value), the national orientation of education (the focus of education on cooperation with society, state institutions, public organizations), the openness of the education system (an individual comprehensive approach to applicants for education), focusing on educational and cognitive activities (spiritual component, morality, civilizational and planetary thinking, worldview picture of the world, new forms of educational and research process using rationality, experience, intuition), creative orientation (elements of self-organization in modern synergetic discourse) (Tsyhanash, 2013, p. 642). There is a change in the system of 
educational values in the civilizational sense, transnational, regional or state dimension. In an axiological sense, educational mobility, on the one hand, provides the goal of increasing the efficiency of the scientific process, on the other, it destroys the established traditional norms of the formation of a certain cluster. Using the example of Canada, we can trace the processes of internationalization provided precisely by mobility (Chow \& Guppi, 2021). Another axiological constant of educational mobility is the formation of individual value priorities. If we analyze the types of educational mobility by philosophical methods, the problems and shortcomings associated with these processes become apparent. The application of the dialectical method immediately exacerbates the problem of balancing the content and form of educational mobility. A person's desire for new knowledge or impressions is related to the satisfaction of his individual needs (anthropological constant). This cluster ensures the practical realization of educational mobility.

An individual's choice of where to improve his or her individual level of learning, teaching, or his or her qualifications depends on many factors and is determined, as a rule, by better conditions. More advanced training programs, better facilities, and the prestige of foreign educational institutions are components that lead to the increased mobility of students, pupils, teachers, or scholars. In this case we are talking about anthropological aspects, which are relevant for a person seeking to improve his educational status. Dewey (2002) believed that true education is realized when a child's abilities are awakened by the demands of the social situations in which he or she finds himself or herself. These demands compel the child to function as a full member of society, to break out of its inherent narrow limits of action and feeling, and to express itself in terms of the values of the group to which it belongs. This attitude shows the anthropological factor conditioning the process of educational mobility in the future. At the same time, this attitude is quite conservative, as it implies a conscious desire of the individual to improve his or her abilities, starting from the school years. While many mobility studies focus on occupational and economic indicators, such as earnings, income, occupational class, or professional status, we seek to refocus the importance of the question in educational terms (Torche, 2019). Schooling is, in fact, a separate and important socioeconomic sphere where its own rules apply and its own values function. At the same time, the axiological aspect of educational mobility is veiled in a certain way.
Any process, phenomenon or object has a value load in one way or another.

This applies to material values, spiritual components, or developmental milestones. In general, a person's ability to learn and change the type of activity during life is conditioned by a number of reasons, which can be divided into internal and external. Internal ones include personal qualities, previous education, environmental influences, etc. External ones imply changes in the micro- and micro-social dimension: changes in profession, family circumstances, economic factors, etc. (Prokhorenko, 2017, p. 169). Education in the idealistic philosophical understanding implies internal spiritual growth, self-improvement, selforganization. The purpose of education is to assist the individual in the full disclosure of his unique potential.

Education involves the realization of abilities and their use in professional or everyday reality. Another undoubtedly important component of educational mobility is the problem of selforganization, which is actualized in the modern worldview paradigm.

"Human life is a continuous journey during which the phenomenon of self-education is embodied in the individual self" (Khrypko, 2010, p. 255). Self-education accompanies an individual throughout his/her professional life. Mobility is an effective tool for realization of synergetic components of human selforganization. Myhovych (2019) refers to mobility as a tool for exchange and experience, as well as the construction of relational capital. European countries have a large number of mechanisms of financial support for mobility as a basis and component of the process of internationalization of national systems of higher education of countries. Statistical data indicate the intensity of mobility, i.e., the growth of the number of participants in the process over a certain period of time. Stimulating factors include:

1) Limited traditional learning at home, in its socio-cultural environment, which leads to further return of the subjects of the educational process;

2) Partial limited learning at home and much lower returns on education, which leads to the final migration - the final move to another country.

The axiological constant regulating communicative norms for subjects of educational 


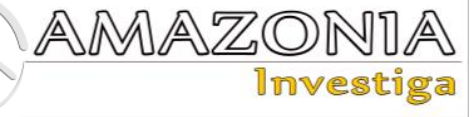

mobility in modern information society is also proposed.

The flow of information is so rapid that there is a need to systematize the available educational information (educational offers) and forms of its implementation (migration problem, distance learning, etc.). According to Shvydun (2021), at the present stage of functioning of Ukrainian institutions of higher education, academic mobility should include: the creation of an information database on international academic mobility programs; ensuring an adequate level of preparation of higher education applicants to study abroad and overcome the language barrier; internationalization of plans and programs. The modern world is drowning in information, which covers almost the entire spatial and temporal element of the ordinary and practical life of man. Value contradictions at the level of "informativeness-communicativeness" take place in the system of educational mobility. At the same time, this flow of information requires feedback. The issue of communication is actualized. For educational mobility informative and communicative function is fundamental, because receiving and exchanging relevant information allows to obtain proper knowledge, skills, and abilities. It is not only people who become mobile in the educational process, but also a large range of participants, in particular different kinds of "objects", “images", "information" (Urry, 2000). Consequently, we get another value base element of educational mobility, which implies the availability and accessibility of information (Urry, 2000).

Yang \& Cheng (2018) substantiate the view that current concerns about the impact of the fourth industrial revolution on learning processes are colored by technocratic discourses that ignore the experiences of the excluded and marginalized in the field. Consequently, the philosophy of education, as a separate cluster of worldview paradigm, regulates the processes that determine the information support of the educational process. An important axiological constant is the identification principle of educational mobility in the paradigm of globalization. The modern sociocultural space is characterized by dynamism, displacing stable, conservative development of all spheres of social life. Features of the functioning of the current civilization are based on scientific and technological advancement, globalization and informatization.

Under such conditions, mobility as a category of development is a key component that ensures competitiveness in the modern world. It is clear that education cannot stand apart from general civilizational trends. As a rule, educational processes are in the vanguard of change and form the vectors of development of worldview paradigms. So far, it can be affirmatively stated that the mobility effect is gradually embracing more and more fundamental educational components. The contradiction of the categories of "globalization-identity" pervades all spheres of contemporary sociocultural space.

The educational sector, with its mobility cluster in particular, is no exception. Conservatism (identification component) in education is still a significant influence. The axiological postulate that education provides adaptation not to life, but to established norms, provides identification of the subject and identification of the education system itself. Such guidance openly hinders integration processes in education. However, the globalistic trends of the modern world, powerfully fueled by scientific, technological, and informational progress, still gradually prevail conservative sentiments in education. Consequently, educational mobility is an important tool of integration processes in society.

The process of choosing where to study becomes an adventure: individual students rationalize their choices through self-reflection and integrative consideration of personal aspirations, the influence of family, social environment, finances, and cultural differences. The axiological caveat outlined by Andrushchenko \& Svyrydenko (2016, pp. 8-9) is relevant. Further containment of innovation, the carriers of which are the participants of academic exchange programs, in favor of mechanical preservation of the traditions of domestic education hinders modernization processes and does not allow us to talk about the future of education in terms of advanced development. At the same time, excessive enthusiasm for innovation, which is brought by participants of academic exchange programs, can lead to the loss of spiritual assets of the Ukrainian educational tradition, and in general to the loss at all levels of understanding that any "new" is ontologically rooted in already known and discovered by humanity, and suggests that the contradictions of innovative educational development must be resolved using the potential of philosophy as a theory and methodology of its development. It is philosophy of education that is able to reach a special level of comprehension of the problem, evaluating all the pros and cons of domestic educational traditions and proposed innovations, making futurological forecasts of the prospects of their introduction, etc. In the 
third millennium it is advisable to talk about stability in education not as a frozen and immovable, but as a constant rational movement forward, conscious renewal of development mechanisms through the introduction of innovations. Developed countries use international education as one of the tools to attract young, capable of learning and an active segment of human capital to national economies. Ukraine's participation in the Bologna process and deepening cooperation with the EU creates new opportunities for Ukrainian youth to receive a high-quality European education and at the same time brings with it traditional threats associated with any other type of international migration. Much is known about the factors that support or limit student mobility, but very few studies have made comparisons between those involved in mobility and those who prefer the traditional form of study (Souto-Otero, Huisman, Beerkens \& de Win and Vujic, 2013). Without this kind of analysis, it is difficult to talk about the effectiveness of mobility. However, by comparing the conditions for participants and non-participants in educational mobility (without their direct testimony), it is possible to analyze the general axiological parameters of this process. Some studies analyze the relationship between students' motivation and their intention to participate in study abroad programs, using a model based on expectancy theory (Sanchez, Fornerino and Zhang, 2006). An important deterrent to the introduction of educational mobility ideas in Ukrainian universities is their traditional and conservative nature. And it is not only about the systemic conservatism of the educational institution, but, above all, the conservatism of the views of the faculty and research staff. There is reason to argue that due to the low level of openness of domestic educational and scientific systems, undeveloped international vector of their activities it is even possible to alienate the individual, when it can become an "outsider at home", which, in the worst case, may lead to the need to fit into the previously abandoned context at the cost of elimination from their practice approaches and knowledge that do not fit into the existing academic or corporate tradition of the university (Andrushchenko \& Svyrydenko, 2016). A rather stereotypical view of conservatism as an element of educational regression. In this case, the conservatism of domestic education provides an identification constant of the educational process. According to the authors, such a constant is important, because it allows you to save all the positive elements of the uniqueness of the Ukrainian educational tradition. Value constant associated with the purpose of educational mobility is expressed by the target component in a humanistic-pragmatic manifestation. Value contradictions within the categories of "humanism-pragmatism" are also in educational mobility. On the one hand, the anthropological dimension of mobility implies the provision of pragmatic components for its subjects. In addition, the value dimension implies the preservation of humanistically oriented priorities. This means that the subjects of educational mobility must adhere to the norms and rules inherent in humanistic ideals. The implementation of the target component of educational mobility can be found in the norm of Article 65 of the Law of Ukraine No. 1709- IX "On General Secondary Education" refers to international academic mobility. In particular, the international academic mobility of students and teachers is realized through their participation in bilateral and multilateral international exchange programs for students and/or teachers. Subjects retain their status and place of study (work) at the relevant educational institution in Ukraine. Analyzing the article from the current legislation, we face the contradiction between the anthropological and axiological elements we have mentioned. On the one hand, the right to mobility and obligations of the subject (anthropological component), but on the other hand, the ultimate goals and purpose of such a process are not specified. That is, we are faced with a certain ambiguity. Educational mobility presupposes exclusively the realization of the individual aspirations of the subject of this process. Obviously, it would be appropriate to prescribe target programs of educational mobility, which will provide a predictable effect on the educational, scientific, social, economic, and other spheres of public life. It is so accepted in society that moving up in society's social hierarchy is associated with positive characteristics. They are endorsed, greeted, and encouraged - as opposed to constancy and conservatism. And in the sense-life components of the dominant culture, to be modern means to be mobile, to cultivate a desire to change places, both territorially and socially. For the individual, mobility is not primarily, but not least, a way of competing for social recognition and personal fulfillment.

At the same time, both upward and downward mobility events take place in a sociocultural space, where the socially oriented aspirations of subjects embodied in action collide with the structural features of institutions that facilitate or limit them (Makieiev \& Oksamytna, 2013, p. 4). Indeed, our society is accustomed to stereotypical value paradigms. It is believed that 


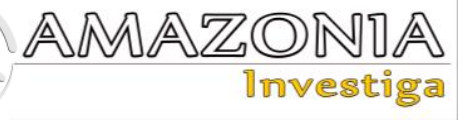

moving "forward" or "upward" is in itself already progressive. However, it should be noted that partly during such a movement, value elements are lost and leveled. Thus, not just opportunities for educational mobility are formed, but also the goal of this process is proclaimed. Giving the process of educational mobility a value-oriented component allows to reduce the risks of uncontrollable and chaotic migration processes, stops the systematic outflow of human resources. O. Rohova (2010) notes that axiological approach is traditionally considered to be one of the methodological foundations of humanistic pedagogical education, because it is aimed at formation of humanistic value orientations of the student and because a human being is considered in it as the highest value of society and the goal of social development. In this connection, axiology, which is more general in relation to humanistic issues, may be considered as the basis for a new philosophy of education and, accordingly, the methodology of modern pedagogy.

The axiological approach allows us to find out the qualities and properties of objects, phenomena, processes capable of satisfying the needs of an individual and a certain society, as well as ideas and motives in the form of norms and ideals. So, in our opinion, one of the basic categories for building a humanitarian paradigm of education can be the category of values. System education is defined by the following axiological clusters: Internal values of the functioning of education (the key in this aspect is the individual axiological aspects concerning both the teacher and the student). External values, having a request from society, by the state. This is how the economic justification of values and further economic justification of educational process organization is formed. Instrumental values of education, concerning individual-oriented social, intellectual, symbolic capital. As an example: dependence of remuneration on the level and quality of education and education as a way and tool for raising social status (social prestige of education). Produced values in education imply formation of free and responsible personality; formation of worldview axiological attitudes of civilization universal character, providing conditions for free self-determination The listed value blocks are a kind of coordinate system, in which education becomes a value concept, and values are somehow expanded and concretized, contributing to the formation of humanitarian paradigm. Andrushchenko \& Svyrydenko (2016) note that the state of development of higher education system bears signs of hybridity: educational practice demonstrates that university life has not yet been finally deprived of postSoviet heritage, against which there are unproductive attempts on a formal level to introduce European approaches, but parallel educational traditions without their social expertise on efficiency in conditions of postindustrial globalized society. In our opinion, we should strive for fundamental rather than external changes in education. Each representative of the academic environment should be aware of his/her role in the modernization educational processes and represent the agents of these changes, being aware of the social significance of his/her activity.

This means to understand the need to return to the academic environment; to interpret the underlying essence of academic mobility not as an escape from the problems of their own national educational system, but as an opportunity to develop their own social capital and returning to become a carrier of innovation in the Ukrainian academic environment. Based on those aspects that aggravate axiological interpretation of mobile education, Oksamytna (2011) highlights the following unresolved problems: the main mechanisms of institutional conditioning of the reproduction of social inequality and mobility; the influence of public policy on the dynamics of social inequality in society as a whole and educational inequality in particular; the economic, status, and class returns to education; the causes and magnitudes of gaps between education and employment; the causes and magnitudes of gender differences in the processes of social reproduction and class and educational mobility; intergenerational mobility; in particular, in societies with high intergenerational mobility, smaller differences in educational attainment are explained by the common environment (Engzell \& Tropf, 2019).

Having analyzed the advantages and disadvantages of educational mobility in its various manifestations (types), we can form a certain terminological matrix, which can serve as a basis for determining the axiological constants of this social process. One of the methodological ways of manifesting the axiological priorities of educational mobility is the use of dialectical categories. The authors, proposing axiological constants of educational mobility, try to avoid negative manifestations of this process. Having an integral paradigm of clear and understandable norms, it is possible not just to state the problem, but also to prevent its critical manifestations. The philosophy of pragmatism views educational mobility as a tool, not an end. Consequently, it is 
the pragmatic view, in our view, which is most appropriate in shaping the value paradigm of education in the mobility cluster.

\section{Conclusions}

Educational mobility is the process of acquiring education or knowledge in a new environment. Philosophy of education comprehends educational mobility and the structuring of this process in two fundamental manifestations: anthropological and axiological (value-based).

The use of dialectical method of categorical contradictions allows us to investigate the human measurability of educational mobility process in all its manifestations. Educational mobility in the opposition of globalization and identification, informatization and communication, humanism and pragmatism acquire a value coloring. With this methodological approach, we can not only state the organizational-structural components of educational mobility (anthropological dimension), but also form a target value constant of this process (axiological dimension).

Horizontal dimension (socio-philosophical aspects) and vertical manifestation (professionalqualification elements) involve the formation of value institutions to avoid social and cultural imbalances. The following axiological constants are proposed for educational mobility: identification principle, communicative norms, target component, social tolerance, and individual value priorities. Through the use of these norms there is an opportunity to streamline and balance the process of educational mobility to ensure the interests of all its subjects (participants).

\section{Bibliographic references}

Andrushchenko, V., \& Svyrydenko, D. (2016). Academic mobility in the Ukrainian space of higher education: realities, challenges and prospects of development. [Akademichna mobilnist $\mathrm{v}$ ukrainskomu prostori vyshchoi osvity: realii, vyklyky ta perspektyvy rozvytku]. Higher education in Ukraine [Vyshcha osvita Ukrainy], 2, 5-11 Retrieved October 30, 2021, from http://nbuv.gov.ua/UJRN/vou_2016_2_3. [In Ukrainian].

Chow, A., \& Guppy, N. (2021). Intergenerational educational mobility over the past century in Canada. Canadian Review of Sociology [Revue Canadienne de Sociologie], 58(3), 372-398. https://doi.org/10.1111/cars. 12348
Dewey, J. (2002). My pedagogical credo. Translated by A. Antipova [Moe pedagogicheskoe kredo. Perevod A. Antipova.]. Altruism.Ru. Retrieved October 30, 2021, from https://altruism.ru/sengine.cgi/5/7/8/7/9

Engzell, P., \& Tropf, F. C. (2019). Heritability of education rises with intergenerational mobility. Proceedings of the National Academy of Sciences of the United States of America, 116(51), 25386-25388. https://doi.org/10.1073/pnas.1912998116

Gruijters, R. J., Chan, T. W., \& Ermisch, J. (2019). Trends in educational mobility: How does China compare to Europe and the United States? Chinese Journal of Sociology, 5(2), 214-240. https://doi.org/10.1177/2057150X19835145

Kalinicheva, G. (2015). Academic mobility [Akademichna mobilnist]. Great Ukrainian encyclopedia [Velyka ukrainska entsyklopediia]. Retrieved October 30, 2021, from https://vue.gov.ua

Khrypko, S. (2010). Axiology of education as the secret of vocation and the spiritual essence of the value of life [Aksiolohiia osvity yak taiemnytsia poklykannia i dukhovna sutnist vartosti buttia]. Philosophy of education [Filosofiia osvity], 1-2, 252-270. Retrieved October 30, 2021, from http://enpuir.npu.edu.ua/bitstream/handle/12 3456789/12697/Khrypko.pdf?sequence $=1 \& \mathrm{i}$ sAllowed=y [In Ukrainian].

Law of Ukraine No. 1709- IX. On Complete General Secondary Education, Activity from October 2 2021. Retrieved October 30, 2021, from

https://zakon.rada.gov.ua/rada/show/v06357 29-13\#Text [In Ukrainian].

Makyeyev, S., \& Oksamytna, S. (2013) Class and educational mobility in Ukraine [Klasova ta osvitnia mobilnist v Ukraini]. Visnyk of the Lviv University. Series Sociology. [Visnyk Lvivskoho universytetu. Seriia sotsiolohichna], 7, 3-17 Retrieved October 30, 2021, from http://publications.Inu.edu.ua/bulletins/index .php/sociology/article/view/465 Ukrainian].

Manchul, B., \& Fedkovych, Y. (2021). Disciplinary knowledge: History, evolution, and contemporary scientific status. The European Philosophical and Historical Discourse, 7(2), 31-36. doi: 10.46340/ephd.2021.7.2.5

Myhovych, I. (2019). Mobility as a basis for the national policy of internationalization of higher education systems in Eastern Europe [Mobilnist yak osnova natsionalnoi polityky 


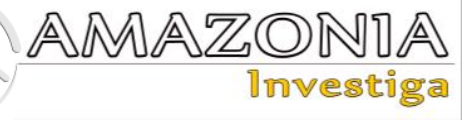

internatsionalizatsii system vyshchoi osvity krain Skhidnoi Yevropy] Bulletin of Taras Shevchenko Lviv National University [Visnyk LNU imeni Tarasa Shevchenka], 1, 215-231 doi: https://doi.org/10.12958/22272844-2019-1(324)-1-215-231 [In Ukrainian].

Oksamytna, S. (2011). Intergenerational class and educational mobility [Mizhheneratsiina klasova ta osvitnia mobilnist]. Kyiv: NaUKMA. Retrieved October 30, 2021, from https://core.ac.uk/download/pdf/149243265. pdf [In Ukrainian].

Prokhorenko, T. (2017). Professional mobility as a factor of professional success. The Bulletin of NLU Law Academy Named Yaroslav the Wise The Series of Philosophy Political Science and Sociology, 4(35), 167-174. https://doi.org/10.21564/20757190.35.119654. [In Ukrainian].

Rohova, O. (2010). Axiological aspect of the humanitarian paradigm of education [Aksiolohichnyi asekt humanitarnoi paradyhmy osvity]. Faces [Hrani], 4, 56-59 Retrieved October 30, 2021, from https://www.libr.dp.ua/text/grani2010_4_13. pdf [In Ukrainian].

Sanchez, C., Fornerino, M., \& Zhang, M. (2006). Motivations and the Intent to Study Abroad Among US, French and Chinese Students. Journal of Teaching in International Business, 2-33. https://doi.org/10.1300/J066v18n01_03

Sorokin, P. (1992). Man. Civilization. Society [Chelovek. Civilizacija. Obshhestvo]. Moscow: Politizdat. Retrieved October 30, 2021, from https://sociology.knu.ua/sites/default/files/lib rary/elclosed/sorokin.pdf [In Russian].

Souto-Otero, M., Huisman, J., Beerkens, M., de Wit, H., \& VujiĆ, S. (2013). Barriers to international student mobility: Evidence from the Erasmus program. Educational Researcher (Washington, D.C.: 1972), 42(2), 70-77. http://dx.doi.org/10.3102/0013189X1246669 6

Shvydun, L. (2021). Educational mobility in the space of the globalized world [Osvitnia mobilnist u prostori hlobalizatsiinoho svitu]. FACES [HRANI.], 24(5), 27-34. Retrieved October 30, 2021, from https:/grani.org.ua/index.php/journal/article/ view/1637 [In Ukrainian]

Sorbonne Joint Declaration. (1998). Joint declaration on harmonisation of the architecture of the European higher education system. Archive.Org. Retrieved October 30, 2021, from https://web.archive.org/web/2009082402572 3/http://www.bolognaberlin2003.de/pdf/Sorbonne_declaration.pdf

The Bologna Declaration. (1999). Joint declaration of the European Ministers of Education. Retrieved October 30, 2021, from http://web.archive.org/web/20110721202047 /http://www.ehea.info/Uploads/Declarations/ BOLOGNA_DECLARATION1.pdf

Torche, F. (2019). Educational mobility in developing countries. UNU-WIDER. https://doi.org/10.35188/UNUWIDER/2019/724-8

Tsyhanash, A. (2013). The role of academic mobility in professional development of future specialists [Rol akademichnoi mobilnosti u profesiinomu rozvytku maibutnikh fakhivtsiv]. Collection of scientific works of K-PNU named after Ivan Ogienko, Institute of Psychology named after G. Kostyuk NAPS of Ukraine [Zbirnyk naukovykh prats K-NPU imeni Ivana Ohiienka, Instytutu psykholohii imeni H. S. Kostiuka NAPN Ukrainy], 641-654 Retrieved October 30, 2021, from http://nbuv.gov.ua/UJRN/Pspl_2013_22_55 [In Ukrainian].

Urry, J. (2000). Sociology beyond societies. Mobilities for the twenty-first century. London \& New York: Routledge. Retrieved October 30, 2021, from https://edisciplinas.usp.br/pluginfile.php/441 0560/mod_resource/content/0/John\%20Urry

Sociology $\% 20$ Beyond $\% 20$ Societies_\%20M obilities\%20for\%20the $\% 20$ Twenty $\% 20$ First $\% 20$ Century $\% 20 \% 28$ International\%20Libra ry\%20of\%20Sociology\%29\%20\%282000\% 29.pdf

Yang, P., \& Cheng, Y. (2018). Educational Mobility and Transnationalization. In Higher Education in the Era of the Fourth Industrial Revolution (pp. 39-63). Singapore: Springer https://doi.org/10.1007/978-981-13-0194$0 \_3$ 